\author{
Joanna Pachucka
}

\title{
Rola lokalnych grup dzialania w kształtowaniu wizerunku turystycznego jednostek terytorialnych
}

\section{Wstęp}

Polityczne i gospodarcze zmiany, jakie nastąpiły w Polsce po roku 1989 w połączeniu z reformami samorządu terytorialnego przyczyniły się do rozwoju koncepcji aktywizacji jednostek samorządu terytorialnego (JST) pod kątem ich konkurencyjności na rynku. Postrzeganie JST w kategoriach podmiotu quasi-gospodarczego w naturalny sposób doprowadziło do poszukiwania przez ich władze innowacyjnych rozwiązań zarządczych i do zorientowania podejmowanych działań na marketingowe koncepcje zarządzania JST, z koncepcją marketingu terytorialnego na czele.

Marketing terytorialny, zrodzony na kanwie poszerzania tradycyjnej koncepcji marketingu oraz przenoszenia i adaptowania metod, technik marketingowych stosowanych w biznesie na grunt terytoriów i miejsc, był naturalną odpowiedzią na rodzące się zapotrzebowanie ze strony jednostek terytorialnych, próbujących odnaleźć się w zmienionej rzeczywistości. W tej nowej, trudnej i wymagającej rzeczywistości ,każda jednostka terytorialna, w tym także gmina, podobnie jak przedsiębiorstwa, podlega prawom rynku, stąd też jest zmuszona rywalizować

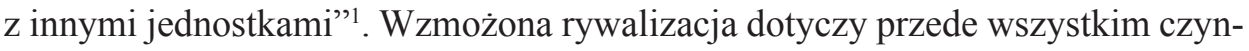
ników rozwojowych jednostek osadniczych, zwłaszcza w takich obszarach, jak pozyskiwanie inwestorów, przyciąganie turystów, zdobywanie funduszy unijnych na rozwój czy poprawa warunków bytowych mieszkańców i zwiększanie ich liczby. Sprawne konkurowanie na coraz bardziej wymagającym rynku wymaga tworzenia, osiągania i utrzymywania przewag konkurencyjnych w czasie. Uznaje się, że ,konkurencyjność regionu jest środkiem do osiągnięcia trwałego

${ }^{1}$ W. Kuźniar, Wdrażanie marketingu terytorialnego na poziomie gminy jako innowacyjna forma zarządzania jednostka terytorialna, [w:] Transfer wiedzy i działań innowacyjnych w obszarze agrobiznesu: uwarunkowania, mechanizmy, efekty, red. S. Makarski, Wyd. Uniwersytetu Rzeszowskiego, Rzeszów 2007, s. 192. 
i zrównoważonego rozwoju"2, stąd też celem zdecydowanej większości jednostek terytorialnych jest podnoszenie konkurencyjności terytoriów wszystkimi dostępnymi sposobami, przy wykorzystaniu endogenicznego potencjału poszczególnych miejsc. Marketing terytorialny jawi się tu zarówno jako podstawowe narzędzie wspomagające wzmacnianie pozycji konkurencyjnej, jak i innowacyjne, systemowe i kompleksowe podejście do zagadnień zarządzania jednostką osadniczą.

„Nowa rzeczywistość społeczno-gospodarcza stawia przed jednostkami samorządu terytorialnego nowe wyzwania i cele"3. Pamiętać tu jednak trzeba, iż specyfika marketingu terytorialnego dotyczy przede wszystkim stopnia złożoności i struktury celów oraz ich wewnętrznej hierarchii ważności, dalece odmiennych od odnotowywanych w marketingu przedsiębiorstw. Na pierwszy plan wysuwa się tu kontekst funkcjonowania samorządu, gdyż „kadencyjność organów gminy odzwierciedla się w priorytetach aktywności gminy"4 i sprawia, że przy zawsze ograniczonych środkach publicznych, będących w gestii samorządu, bieżące potrzeby i populistyczne działania o łatwo dostrzegalnych w krótkim okresie efektach na ogół wygrywają z innymi koncepcjami, np. finansowania działań o charakterze marketingowym, których efekty trudniej dostrzec, są mniej mierzalne/namacalne lub których rezultaty są po prostu rozłożone w czasie.

Okazuje się jednak, że jeśli tylko uda się przezwyciężyć krótkowzroczność, przyjmie się aktywną postawę oraz dłuższą perspektywę, postawi na spójną, dobrze przemyślaną koncepcję o orientacji marketingowej, opartą na fundamentalnych zasadach marketingowych to efekty tych działań staną się widoczne.

Takim pozytywnym przykładem jest miasto Zambrów w województwie podlaskim. W latach dziewięćdziesiątych XX wieku miasto borykało się z typowymi problemami ośrodków o socjalistycznej industrialnej przeszłości, których przemysłowa świetność oparta na jednej branży minęła wraz z końcem PRL-u, problemami takimi jak bezrobocie, zły stan infrastruktury miejskiej czy emigracja zarobkowa mieszkańców. Mając świadomość narastającej rywalizacji ośrodków miejskich o rozpoznawalność, unikatowość wizerunku, o inwestorów, turystów i inne czynniki rozwojowe lokalne władze samorządowe stworzyły strategię kształtowania wizerunku nie wbrew, ale w zgodzie z atrybutami socjalistycznej tożsamości miasta. Nie odcinając się od przeszłości, nie deprecjonując historii

${ }^{2}$ E. Ferens, Marketing terytorialny jako narzędzie budowania przewagi konkurencyjnej jednostek terytorialnych, [w:] Marketing terytorialny w budowaniu konkurencyjności podmiotów publicznych, red. A .Siedlecka, Wyd. Państwowej Wyższej Szkoły im. Jana Pawła II w Białej Podlaskiej, s. 20.

${ }^{3}$ W. Kuźniar, op. cit., s. 195.

${ }^{4}$ D. Guzal-Dec, Rola marketingu terytorialnego w zarzadzaniu rozwojem gminy, [w:] Marketing terytorialny..., s. 57. 
postanowiono wykorzystać postsocjalistyczny wizerunek miasta do budowania jego współczesnej tożsamości. W upadłych Zambrowskich Zakładach Przemysłu Bawełnianego stworzono Zambrowski Park Przemysłowy, dzięki wykorzystaniu środków unijnych, zwłaszcza z programu operacyjnego Rozwój Polski Wschodniej 2007-2013, poprawiła się infrastruktura miejska (zmodernizowano i rozbudowano sieć wodociągową i kanalizacyjną, dróg gminnych czy sieć telekomunikacyjną) i estetyka samego miasta, odnotowano wzrost zainteresowania mieszkańców sprawami miasta. W rankingu „Gazety Prawnej” i Ministerstwa Rozwoju Regionalnego „Europejska Gmina, Europejskie Miasto” miasto Zambrów uzyskało tytuł laureata w województwie podlaskim w roku 20085. Akcja „Doceń Zambrów” znalazła się w półfinale konkursu „Podlaska Marka Roku 2007 ".

Nadmienić trzeba tu jednak, iż „spójność prowadzonej polityki miejskiej wynika w dużej mierze $\mathrm{z}$ faktu, że obecny burmistrz Zambrowa zajmuje swoje stanowisko już trzecią kadencję" , co jest nie do przecenienia. Kontynuacja bowiem raz przyjętego kierunku, jeśli został on dobrze i szczegółowo przemyślany, może przynieść pożądane pomyślne efekty, i to efekty długookresowe, a te są najcenniejsze. Nie ma nic gorszego niż diametralna zmiana wcześniej przyjętego planu z niewłaściwych pobudek, w tym personalnych czy politycznych, bez wcześniejszej obiektywnej oceny jego merytorycznej wartości. Niezależnie jednak od wzmiankowanego przykładu wydaje się, iż skoncentrowanie uwagi na priorytetach samej społeczności lokalnej, na działaniach, które przynosić będą korzyści gminie jako całości, przy zachowaniu stałego monitoringu oczekiwań mieszkańców danej jednostki osadniczej, oraz konsekwencja w działaniu, to jedyne sposoby pozwalające przynajmniej częściowo zniwelować mankamenty funkcjonowania samorządu związane z jego kadencyjnością.

„Rozwój konkurencji na rynku ofert miejskich zmusza nawet niewielkie miejscowości do poszukiwania pomysłów na zaistnienie w społecznej percepcji, na kształtowanie wyrazistego wizerunku w warunkach rynkowych"8. Niezmiernie ważna w realizacji tych pomysłów jest nowatorska, ale jednocześnie spójna wizja przyszłości oraz konsekwencja i wytrwałość w dążeniu do celu.

${ }^{5}$ http:// zambrow.org/ aktualności/ Nasze gminy w rankingu „Europejska Gmina, Europejskie Miasto" [dostęp: 26.10.2010].

${ }^{6}$ http:// zambrow.org/ aktualności/ „Akcja Doceń Zambrów nie znalazła się wśród nominowanych do Marki Roku" [dostęp: 25.02.2008].

${ }^{7}$ E. Glińska, A. Kowalewska, Ksztaltowanie wizerunku miasta postsocjalistycznego na przykładzie Zambrowa, [w:] Marketing terytorialny. Studia przypadków, red. M. Florek, K. Janiszewska, Wyd. Akademii Ekonomicznej w Poznaniu, Poznań 2008, s. 40.

${ }^{8}$ Ibidem, s. 40. 


\section{Budowanie przewagi konkurencyjnej a wizerunek}

Za dalece pozytywne zjawisko uznać należy mentalną zmianę wśród włodarzy miast i regionów w podejściu do korzystania z dorobku marketingu w ,codziennej egzystencji” jednostek samorządu terytorialnego. Wyraźnie widać, że zaczęli dostrzegać i doceniać wymierne, choć nie natychmiastowe, korzyści jakie można w ten sposób kreować i osiągać. „Analizując ostatnie lata działalności przedstawicieli władz samorządowych zauważyć można rozwijającą się świadomość prowadzenia działań marketingowych, mających na celu zwiększenie rozpoznawalności miast. Inwestowane są coraz większe środki finansowe, służące budowaniu marki jednostek samorządu terytorialnego, kreowaniu pozytywnego wizerunku zgodnego z oczekiwaniami włodarzy. Całość działań wspierana jest przygotowanymi strategiami rozwoju czy marketingu, których wdrażaniu towarzyszy spójna komunikacja" . Podejmowane działania marketingowe powinny jednak zawsze opierać się na ewidentnych atutach danej jednostki terytorialnej. Wówczas dążenia do wykreowania faktycznej przewagi konkurencyjnej będą wiarygodne, a przewaga trwała i unikatowa.

Bez zbudowania jednak, wyraźnie odróżniającej daną jednostkę terytorialną od innych jednostek, przewagi konkurencyjnej, opartej na faktach, atrakcyjnej i niepowtarzalnej, prezentującej w oczach różnego typu odbiorców nadwyżkowe walory wobec tych oferowanych przez konkurentów, nawet wysoko budżetowe działania marketingowe mogą okazać się nieskuteczne. Źródeł przewagi konkurencyjnej jednostki terytorialnej szukać można w różnego typu zasobach, począwszy od zasobów miejscowych o charakterze naturalnym, infrastrukturalnym, społecznym, kulturalnym, przez zasoby finansowe, techniczne i organizacyjne, na zasobach niematerialnych skończywszy.

„Współcześnie na rynku terytorialnym kluczowe znaczenie ma jakość oferowanych produktów, ich właściwe pozycjonowanie i wizerunek. Jakość i wizerunek stanowią podstawę budowania trwałej przewagi konkurencyjnej w ujęciu terytorialnym”10. Świadczyć o tym może choćby i to, że „wśród strategicznych celów marketingowych samorządowych wspólnot terytorialnych [...] pojawia się coraz częściej cel związany z kształtowaniem wizerunku marketingowego..." Coraz częściej także uważa się, że „zorientowanie strategii marketin-

${ }^{9}$ A. Kijanka, Rozrywka jako element kreowania wizerunku miast i rozwoju patriotyzmu lokalnego, [w:] Wizerunek regionu o orientacji rynkowej, red. A. Siedlecka, A. Smarzewska, M. Zwolińska-Ligaj, J. Kamiński, Wyd. Państwowej Szkoły Wyższej im. Papieża Jana Pawła II w Białej Podlaskiej, Biała Podlaska 2012, s. 45.

10 J. Szwacka-Mokrzycka, Budowanie przewagi konkurencyjnej jednostki terytorialnej, „Studia Ekonomiczne i Regionalne" 2012, nr 1, s. 74.

${ }^{11}$ A. Szromnik, Marketing terytorialny. Miasto i region na rynku, Oficyna Wydawnicza Wolters Kluwer Business, Kraków 2007, s. 130. 
gowych na kształtowanie image’u jest wyrazem ogólnych trendów w rozwoju osadnictwa"12.

Wizerunek miejsc, kształtowany w długiej perspektywie czasowej, wewnętrznie złożony, zmienny i wysoce zindywidualizowany, jest kategorią o dużym stopniu skomplikowania, wielowymiarową oraz wielopłaszczyznową. Ten mentalny obraz miejsca, silnie subiektywny, to konstrukcja dość niewdzięczna jako przedmiot oddziaływania, stąd też wykreowanie lub zmiana istniejącego wizerunku to zadania trudne oraz czaso- i pracochłonne. Widać to już na poziomie definicyjnym samego pojęcia czy też w wielości istniejących definicji. W podsumowaniu przeglądu różnych definicji wizerunku miejsca A. Szromnik pisze ,uogólniając [...] poglądy i opinie, stwierdzić można, że wizerunek miasta to całokształt subiektywnych wyobrażeń rzeczywistości, które wytworzyły się w umysłach ludzkich jako efekt percepcji, oddziaływania środków masowego przekazu i nieformalnych przekazów informacyjnych, [...] mentalny obraz miasta, jego wewnętrzne odbicie w umysłach różnych jednostek i grup społecznych..." ${ }^{13} \mathrm{~W}$ tym miejscu autor odnosi się do rzeczywistości miejskiej, ale interpretacja ta może być bez trudu kierowana do wszelkiego typu miejsc - gmin, powiatów, regionów, a nie tylko miast. Dodatkowych trudności przysparza fakt, że wizerunek miejsca zawsze łączy w sobie składowe twarde (racjonalne) i miękkie (emocjonalne). „Marketingowy wizerunek jednostki osadniczej [...] składa się z kombinacji elementów realnych i pozarealnych. Według R. Junghardta elementy realne wizerunku [...] to wszystkie postrzegalne fakty, które można pojąć w sposób racjonalny. [...] Elementy te ze względu na ich fizyczny charakter są relatywnie łatwe do sprecyzowania i uporządkowania. Elementy pozarealne mają charakter emocjonalny i wyrażają osobisty stosunek osoby lub grupy do rozpatrywanej miejscowości. Przejawiają się jako określone nastawienia uczuciowe, jako świadome lub podświadome wrażenia oceniające ukształtowane w danej mierze pod wpływem własnych, subiektywnych życzeń i obaw"14. Pozarealne elementy wizerunku oparte są zatem zawsze na emocjach, wyrażają osobisty stosunek osoby/grupy do danego miejsca. I tu pojawia się wcześniej wspomniana trudność. Okazuje się bowiem, iż oddziaływanie na elementy realne wizerunku jest prostsze. Dużo trudniej jest wpływać na elementy miękkie, pozarealne, emocjonalne wizerunku. „Raz wytworzone nastawienie wobec konkretnego miasta jest trwałe, funkcjonuje w psychice człowieka przez długi czas, nawet jeśli jest oparte na uprzedzeniach. Stanowi jego indywidualne, subiektywne spojrzenie, ocenę własną miasta jako całości lub jego różnych składników. [...] Turyści, inwestorzy, migranci i inni klienci

\footnotetext{
${ }^{12}$ Ibidem, s. 131.

13 Ibidem, s. 134.

${ }^{14}$ Ibidem, s. 144.
} 
miasta kierują się w swych decyzjach charakterystykami realnymi. Często jednak ich zachowania i postawy wynikają z ocen emocjonalnych, z ich uczuciowego odbioru miejscowości" ${ }^{15}$, a dokonanie zmian w obrębie tych charakterystyk jest znacznie bardziej skomplikowane i wymaga zaangażowania nakładów czasu, pieniędzy oraz niemałego wysiłku intelektualnego włożonego w tworzenie skutecznych programów oddziaływania na osobiste nastawienia poszczególnych adresatów działań marketingowych i ich grup, programów związanych z wizerunkiem danego miejsca i jego zmianą, poprawą czy reorientacją. Kreowanie docelowego wizerunku miejsca ma zawsze służyć wzrostowi jego rozpoznawalności, jako kluczowego elementu budowania przewagi konkurencyjnej na rynku terytorialnym.

\section{Wizerunek turystyczny}

Wizerunek turystyczny miejsca nierozerwalnie wiąże się z pojęciem jego tożsamości (place identity). Przyjmuje się, iż stanowi on transpozycję tożsamości miejsca na obraz percepcyjny w świadomości odbiorcy, w umyśle obiektu odwzorowania. W odniesieniu do wizerunku turystycznego miejsca tym obiektem będzie zawsze turysta, będą to wszystkie osoby przyjeżdżające do danej miejscowości, odwiedzające ją niezależnie od stopnia regularności wizyt czy choćby przejeżdżające przez nią tranzytem. Przyjmuje się również, że tak jak w przypadku tożsamości organizacji, tak i w stosunku do tożsamości jednostki osadniczej ważna jest percepcja tożsamości powstała w wyniku strategicznie zaplanowanego i z góry nakreślonego systemu samoprezentacji, zorientowanego wewnętrznie i zewnętrznie, a opartego na instrumentach komunikacji marketingowej.

Zarówno w sytuacji kształtowania tożsamości miejsca, jak i jego wizerunku, $\mathrm{w}$ tym wizerunku turystycznego, cel jaki przyświeca w tych staraniach (przyświecać powinien) jest zawsze ten sam - kreowanie pozytywnego wizerunku, nastawienia wobec danego miejsca. Oczywiście w stosunku do wizerunku turystycznego chodzi o to, by dane miejsce stało się cenioną destynacją turystyczną. Jeśli się to uda, to o tym jak cenny może być to atut na długi czas, świadczyć może choćby przykład Portugalii i wypracowanego przez ten kraj przez lata pozytywnego wizerunku miejsca wymarzonych wakacji. Lata 2010-2013 były dla Portugalii szczególnie trudne. Kryzys gospodarczy stawał się dla Portugalczyków coraz bardziej dotkliwy. Spadające płace, rosnące bezrobocie, oszczędności budżetowe czy fala protestów społecznych na pewno nie przyczyniały się do poprawy wizerunku kraju na arenie międzynarodowej. „Tymczasem kłopoty ekonomiczne potomków Va-

${ }^{15}$ Ibidem, s. 145. 
sco da Gamy nie mają wpływu na turystyczny wizerunek jego ojczyzny" ${ }^{16}$. Jak to możliwe? Wizerunek to pewien kapitał na lata, buduje się go latami, ale i zmiany w jego obrębie następują w tym samym tempie. „Tysięczne tłumy demonstrują na ulicach miast $\mathrm{w}$ proteście przeciw rządowej polityce cięć i oszczędności, który Lizbonie narzuciła Komisja Europejska i Międzynarodowy Fundusz Walutowy. Według szacunków Krajowego Instytutu Statystycznego dystans pomiędzy Portugalią a pozostałymi członkami Unii Europejskiej powiększa się w coraz szybszym tempie. Tymczasem w aktualnej edycji rankingu portalu podróżniczego Globe Spots za najlepszy kierunek turystyczny 2013 roku została uznana właśnie Portugalia"17. Serwis informacyjny Traveltime.info.pl podaje, że turystyczny region Algarve, kuszący zwłaszcza słońcem i przepięknymi plażami, odwiedza rocznie 11 milionów zagranicznych turystów. Co zatem znaczy siła wizerunku, nawet w obliczu kryzysu ekonomicznego, wydaje się być pytaniem nie wymagającym odpowiedzi.

\section{Rola lokalnych grup dzialania}

W marketingu terytorialnym od zawsze mamy do czynienia z pluralistycznym charakterem kształtowania decyzji marketingowych, zawsze uczestniczą $\mathrm{w}$ tym procesie różne podmioty $\mathrm{i}$ ich grupy. Nie inaczej jest w przypadku kreacji wizerunku danego miejsca.

„W procesie kształtowania wizerunku/image'u miasta uczestniczy wiele podmiotów. Są to: mieszkańcy miasta, władze lokalne, stowarzyszenia i organizacje działające na terenie miasta, lokalne przedsiębiorstwa, masowe media oraz turyści"18.

Wydaje się, że podmiotem nie zawsze i nie w pełni jeszcze dostrzeganym oraz docenianym $\mathrm{w}$ procesach kształtowania wizerunku są lokalne grupy działania. Co prawda ostatnie lata znacząco przyczyniły się do rozwoju Lokalnych Grup Działania, głównie za sprawą wsparcia oferowanego tym grupom w ramach Programu Rozwoju Obszarów Wiejskich 2007-2013 w osiach Leader, Leader II czy Leader+ wsparcia realizowanego z udziałem środków Europejskiego Funduszu Rolnego za pośrednictwem agencji rządowych ${ }^{19}$, lecz ich rola i znaczenie

${ }^{16} \mathrm{http} / /$ www.traveltime.info.pl/ 33-aktualności/49 - turystyczny wizerunek odporny na kryzys.html.

17 Ibidem.

${ }^{18}$ E. Stachura, M. Borowska, Rola dziedzictwa kulturowego w procesie ksztaltowania wizerunku miasta w świetle badań, [w:] Wizerunek regionu..., s. 18.

${ }_{19}$ Agencja Restrukturyzacji i Modernizacji Rolnictwa po zrealizowaniu inwestycji przez LGD dokonuje refundacji części poniesionych kosztów kwalifikowanych, według odrębnych szczegółowych przepisów, w zależności od rodzaju przeprowadzonych działań, np. „Różnicowanie w kierunku działalności nierolniczej’ czy „Tworzenie i rozwój mikroprzedsiębiorstw”. 
w kreacji korzyści wizerunkowych danego miejsca (miejscowości, obszaru czy regionu) jest chyba nieco marginalizowana. Niska jest również sama świadomość istnienia i funkcjonowania lokalnych grup działania, choć statystyki dotyczące ich liczby są dość imponujące. ARiMR podaje, że w Polsce działa obecnie 336 LGD $^{20}$.

Lokalna grupa działania to rodzaj terytorialnego partnerstwa publiczno-prywatnego, złożonego z przedstawicieli sektora publicznego i prywatnego. Jest podmiotem mającym osobowość prawną, występującym najczęściej w formie stowarzyszenia ${ }^{21}$ i zarejestrowanym w Krajowym Rejestrze Sądowym. Punktem wyjścia tworzenia lokalnych grup działania, słuszne zresztą, było założenie, że to właśnie mieszkańcy, wchodzący w skład LGD, wiedzą najlepiej jak powinien rozwijać się dany obszar, jaki obrać kierunek, na czym skupić uwagę, czym przyciągać innych do tego obszaru geograficznego, turystycznego czy przyrodniczego, który zamieszkują nierzadko od pokoleń. Każda lokalna grupa działania opracowuje lokalną strategię rozwoju i w niej precyzuje cele, jakie stoją przed grupą oraz działania, jakie będą podejmowane, by cele te osiągnąć, w tym również działania o charakterze gospodarczym. Każda zmiana w obrębie przyjętej strategii wymaga zatwierdzenia przez walne zebranie członków LGD.

Badania nad wizerunkiem miast pokazują wyraźnie wartość i znaczenie potencjału dziedzictwa kulturowego w procesach kształtowania wizerunku miejsca/ miejsc. Ten potencjał trzeba starać się w sposób umiejętny, ale i mądry, maksymalnie wykorzystać. Podmiotami, które doskonale zaczęły wpisywać się w tę rolę, wykazując się nie tylko dobrą wolą, ale i przedsiębiorczością w myśleniu i działaniu, pomysłowością i umiejętnościami twórczego wykorzystywania zasobów i potencjału historyczno-kulturowego, okazały się właśnie lokalne grupy działania.

Pozytywnym przykładem doskonale przemyślanej koncepcji wykorzystania wcześniej wspomnianego dziedzictwa lokalnego może być wspólna inicjatywa dwóch stowarzyszeń z województwa świętokrzyskiego, powiat ostrowiecki, ze wsi Bałtów - Stowarzyszenia „Delta” i Stowarzyszenia Na Rzecz Rozwoju Gminy Bałtów „Bałt” - JuraPark „Bałtów”. JuraPark to pierwszy w Polsce park tematyczny, zawierający rekonstrukcje dinozaurów naturalnej wielkości, otwarty

${ }^{20}$ Informacja ze strony www. ARiMR.gov.pl.

${ }^{21}$ Przed wejściem w życie ustawy o wspieraniu rozwoju obszarów wiejskich z udziałem środków Europejskiego Funduszu Rolnego na rzecz Rozwoju Obszarów Wiejskich z dnia 07.03.2007 r. w tworzeniu LGD mogły uczestniczyć także fundacje i związki stowarzyszeń. Dziś ustawa w art. 15 wyraźnie mówi o formie stowarzyszenia, dla nowo tworzonych LGD. Członkiem zwyczajnym LGD może być osoba fizyczna, jak i osoba prawna, w tym także jednostki samorządu terytorialnego, z wyłączeniem województw (art. 15, pkt 1, ppkt 1). 
07.08.2004 roku ${ }^{22}$. Powstanie JuraParku było odpowiedzią lokalnej społeczności na rozpoczęte w 2001 roku na terenie gminy badania Państwowego Instytutu Geologicznego w Warszawie. Doktor Gerard Gierliński, który zapoczątkował prace badawcze, podążając śladami ludowych legend, natrafił w tym miejscu na późnojurajskie ślady drapieżnego dinozaura - allozaura. Odkrycie geologów postanowili wykorzystać lokalni patrioci, widząc w tym wyjątkową szansę dla rozwoju gminy. Utworzenie Lokalnej Grupy Działania JuraPark „Bałtów” pozwoliło nie tylko na budowę Bałtowskiego Parku Jurajskiego, ale pokazało, jak wykorzystując lokalne atuty i historyczne dziedzictwo zainteresować turystów miejscem dotychczas nieznanym, zmieniając tym samym jego losy i życie mieszkańców gminy, nie wspominając o rozpoznawalności jej wizerunku czy pozyskaniu wyróżniającej przewagi konkurencyjnej na rynku terytorialnym. Na efekty nie trzeba było długo czekać, a pomysłowość i praca zaangażowanych w przedsięwzięcie ludzi zaczęły przynosić konkretne rezultaty. Już wkrótce po otwarciu Bałtowskiego Parku Jurajskiego stał się on wizytówką regionu świętokrzyskiego, przyciągając z okresu na okres coraz liczniejsze rzesze odwiedzających. Na efekt śniegowej kuli nie trzeba zbyt długo czekać, sukces parku pociąga za sobą rozwój miejscowości. Park potrzebuje odpowiedniego zaplecza, choćby hotelarskiego, czy dodatkowych atrakcji turystycznych uzupełniających dotychczasową ofertę, co w pozytywny sposób oddziałuje na lokalny rynek pracy i sytuację finansową gminy. Jedna inwestycja przyciąga kolejne. W gminie rozwija się agroturystyka, tworzy się baza noclegowa i gastronomiczna, kolejne pomysły i nowe przedsięwzięcia wcielane są w życie. Kolejno powstają Zwierzyniec Bałtowski - 40 hektarowy park z wolnym wybiegiem dla jeleni, danieli, kozic, lam, owiec, koników polskich i osłów, Kamienne Oko - czynne sezonowo miejsce do kąpieli. W roku 2009 powstaje Kraina Koni - ośrodek jazdy konnej, nauki jazdy i hotel dla koni, w 2011 roku Kino Emocji - kino 5D²3. Dziś JuraPark Bałtów to już całoroczny kompleks turystyczny z parkiem tematycznym liczącym sto modeli dinozaurów w skali $1: 1^{24}$, parkiem rozrywki, wioską czarownic, ścieżkami edukacyjnymi, skansenem pszczelim, spływem rzeką Kamienną, stacją narciarską, zwierzyńcem czy prehistorycznym oceanarium. Z roku na rok wzrasta liczba odwiedzających park. Według danych portalu parkmania.pl w roku 2007 było to około 300 tysięcy zwiedzających, w 2008 roku 360 tysięcy, a w roku 2009 prawie 500 tysięcy. Park zawdzięcza swą wzrastająca popularność nie tylko dobrej promocji, marketingowi szeptanemu czy nagrodom zdobywanym w licznych konkursach, jak

\footnotetext{
22 www.juraparkbaltow.pl.

23 www.juraparkbaltow.pl.

24 www.parkmania.pl.
} 
choćby nagroda Turystyczny Produkt Roku $2005^{25}$ w konkursie Polskiej Organizacji Turystycznej na Najlepszy Produkt Turystyczny, Laur Świętokrzyski 2009 w kategorii Człowiek Roku dla pomysłodawcy Juraparku - Nagroda Wojewody Świętokrzyskiego za wkład w rozwój i promocję regionu świętokrzyskiego ${ }^{26}$ czy nagroda Popularyzatora Nauki 2012 dla Stowarzyszenia „Delta” - właściciela parku, przyznawana przez MNiSW i PAP ${ }^{27}$, ale także, a może przede wszystkim, stworzeniu własnej niepowtarzalnej tożsamości i pozytywnego, oryginalnego wizerunku miejsca, które na stałe związały się z tym terenem i teraz procentują, niczym kapitał na dobrej, długoterminowej lokacie. Po sukcesie JuraParku w Bałtowie Stowarzyszenie „Delta” otwiera kolejne ,juraparki” w Solcu Kujawskim i Krasiejowie koło Opola ${ }^{28}$.

Budujących przykładów jest więcej. Można je odnaleźć nawet w obrębie tego samego województwa - województwa świętokrzyskiego. Stowarzyszenie Lokalna Grupa Działania „Wokół Łysej Góry” realizuje projekt pod nazwą Kraina Legend Świętokrzyskich. Wśród elementów składowych przedsięwzięcia znalazły się warsztaty teatralne, gry i zabawy terenowe, wędrówki szlakiem legend, a także projekt o charakterze edukacyjnym Osada średniowieczna w Hucie Szklanej, rekonstrukcja średniowiecznej wioski, w której oprócz wizytacji samych obiektów można także poznać tajniki zapomnianych już dziś rzemiosł (tkactwo, rymarstwo, garncarstwo czy kowalstwo), a po trudach zwiedzania posilić się i odpocząć w średniowiecznej karczmie ${ }^{29}$. Osada zarządzana jest przez powołaną do życia w 2010 roku przez gminę Bieliny organizację Centrum Tradycji i Turystyki Gór Świętokrzyskich. Osiągając cele ogólnospołeczne, jak choćby edukacyjne czy związane z zachowaniem lokalnych tradycji i umiejętności rękodzieła zarówno organizacja, jak i lokalna grupa działania przyczyniają się do rozwoju gminy, wspierania lokalnego rynku pracy i utrwalania pozytywnego wizerunku miejsca, miejsca aktywnych form spędzania wolnego czasu dla dzieci, dorosłych i dla całych rodzin.

W procesie kształtowania wizerunku turystycznego danego miejsca i samego rozwoju turystyki na danym obszarze niezmiernie ważne jest współdziałanie różnych podmiotów, ukierunkowane na tworzenie atrakcyjnego zintegrowanego produktu turystycznego i promowanie jego walorów. W przypadku województwa świętokrzyskiego ,największy udział w kształtowaniu tożsamości turystycznej regionu świętokrzyskiego ma, od czasu jej powołania 10 lat temu, Regio-

\footnotetext{
${ }^{25} \mathrm{https}$ ://pot.gov.pl/certyfikaty-pot.

${ }^{26}$ www.wiadomości.o-c.pl/ Jeszcze wiele pomysłow na Bałtów/ dodano 14.04.2009 r.

27 www. parkmania.pl/ Należące do Stowarzyszenia Delta juraparki nagrodzone prestiżową nagrodą/dodano 23-02.2012 r.

${ }^{28}$ www.parkmania.pl.

29 www.bieliny.pl/ Urząd Gminy Bieliny.
} 
nalna Organizacja Turystyczna Województwa Świętokrzyskiego"30. Organizację można uznać za swoistego koordynatora różnorakich przedsięwzięć na terenie województwa świętokrzyskiego, mających na celu „wykreowanie »czarującej« tożsamości świętokrzyskiego obszaru recepcji turystycznej, a następnie promocję związanego z nią wizerunku turystycznego regionu" ${ }^{31}$. Patronowała np. różnego typu kampaniom promocyjnym, jak „Świętokrzyski Sabat Czarownic” czy „Świętokrzyskie czaruje. Poleć na weekend". Działalność o tym charakterze z pewnością wspiera i łączy w pewną całość działania różnych aktorów lokalnego rynku turystycznego, w tym i lokalnych grup działania.

Ideę wykorzystywania atutów historyczno-geograficzno-przyrodniczych danego terenu dla kreowania jego turystycznego wizerunku i tworzenia nowych szans jego rozwoju, podchwyciły szybko gminy i powiaty z terenu całej Polski, zwłaszcza te o trudnej sytuacji społeczno-ekonomicznej lub o monokulturowych gospodarstwach, widząc w tym szansę na zmianę dotychczasowej sytuacji i licząc na środki ze strony różnych programów pomocowych. Przykłady ilustrujące wspomniane działania gmin i powiatów czy lokalnych społeczności łatwo znaleźć przeglądając chociażby strony internetowe urzędów gmin. Poszukując pomysłów na rozwój i aktywizację danego obszaru, a także później już na etapie wcielania ich w życie, nie można zapomnieć o konieczności zachowania ich unikatowości na skalę czy to lokalną, czy krajową, próbując jednocześnie chronić tradycyjne, historyczne walory tych miejsc. Cel taki postawiła sobie np. Lokalna Grupa Działania „Zielony Pierścień” z siedzibą w Nałęczowie, utworzona w 2008 roku przez przedstawicieli 11 gmin z powiatów puławskiego i lubelskiego w województwie lubelskim, obejmująca obszarem działania region trójkąta turystycznego Nałęczów - Kazimierz Dolny - Puławy32. LGD, uznając wyjątkowość dziedzictwa przyrodniczo-krajobrazowego o wielkim turystycznym potencjale, za cel nadrzędny postawiła sobie zachowanie i ochronę walorów przyrodniczych obszaru przełomu środkowej Wisły i pradoliny Wieprza, a także jego promowanie w celu rozwoju ekoturystyki, jako alternatywnych sposobów zarobkowania mieszkańców obszarów wiejskich. Wśród licznych zadań do realizacji w ramach projektów podjętych przez grupę znalazły się między innymi: utworzenie sieci pętli rowerowych od Kazimierskiego do Kozłowieckiego Parku Krajobrazowego i rozwój infrastruktury turystycznej (agrokwatery, punkty gastronomiczne, wypożyczalnie rowerów), opracowanie strategii rozwoju ekoturystyki, promocja rolnictwa

${ }^{30}$ M. Lemanowicz, H. Szcześniak, Działania promocyjne województwa świętokrzyskiego narzędziem budowy wizerunku turystycznego regionu, [w:] Wizerunek regionu..., s. 77.

${ }^{31}$ Ibidem, s. 77.

32 www. zielonypierscien.pl. 
ekologicznego czy zadania o charakterze edukacyjnym, kreujące postawy proekologiczne wśród dzieci i młodzieży ${ }^{33}$. Powstały też projekty: utworzenia Ekomuzeum Lubelszczyzny „Żywa Tradycja” składającego się z Muzeum Kowalstwa i Wojciechowskiego Muzeum Regionalnego, Serowarni w Zawadzie, Regionalnej Izby Tradycji i Młyna w Celejowie, Tkackiej Izby Regionalnej w Borysowie, Izby Garncarskiej w Baranowie i Muzeum Nietypowych Rowerów w Gołębiu oraz promocji lokalnych produktów poprzez znak promocyjny „Produkt Lokalny Zielonego Pierścienia”. Jeśli realizacja projektów będzie przebiegała pomyślnie, obszar przełomu środkowej Wisły i pradoliny Wieprza ma szansę zyskać znacznie większą rozpoznawalność niż tylko wynikającą z kompleksów sanatoryjnych w Nałęczowie, co przełoży się na bardziej wymierne korzyści, w tym materialne, dla regionu i jego mieszkańców w przyszłości.

Inicjatyw na poziomie lokalnym szukać można niezależnie od województwa. Kolejnym, być może nieco mniej spektakularnym, przykładem kreowania przyjaznych turystom „małych ojczyzn”, może być skansen rzeki Pilicy. Dzięki pomysłowości i zaangażowaniu ludzi związanych ze Stowarzyszeniem Przyjaciół Pilicy i Nadpilicza, powstałego w 1997 roku, skupiającego się na zapobieganiu degradacji środowiska przyrodniczego dorzecza Pilicy zachowaniu bogactwa kulturowego terenów Nadpilicza i upowszechnianiu wiedzy o Pilicy oraz współpracy z UM w Tomaszowie Mazowieckim powstała niezwykła placówka muzealna, żywy i barwny obiekt - skansen poświęcony rzece. Skansen zaczął funkcjonować 19.04.2005 roku, choć jego ideę zaczęto promować już w roku 1998, wraz z początkiem organizowania przez Stowarzyszenie Przyjaciół Pilicy i Nadpilicza corocznych obchodów „Święta Pilicy”34. Dziś można w skansenie zwiedzać następujące ekspozycje: młynarstwo wodne w dorzeczu Pilicy, prezentującą m.in. młyn wodny i kolekcję kamieni młyńskich; fortyfikacje linii Pilicy - ekspozycję poświęconą militariom II wojny światowej (można tu zobaczyć np. oryginalny ciągnik artyleryjski Luftwaffe zatopiony w Pilicy przez Niemców w styczniu 1945 roku, wydobyty z dna rzeki i odrestaurowany); pamiątki po dawnej Spale i architektoniczne osobliwości z Nadpilicza - poświęcone unikatowym perełkom architektonicznym dawnej Spały (zobaczyć tu można np. toaletę carską z przełomu XIX i XX wieku i okresu, kiedy carowie Rosji polowali w spalskich lasach, czy budynek do przechowywania paszy dla żubrów) oraz ekspozycję „oś rzeki Pilicy”, odnoszącą się do tradycji wodniackich, związanych z rzeką Pilicą. Skansen gromadzi różnego rodzaju eksponaty i archiwalia, posiada obszerną bibliotekę wydawnictw o tematyce poświęconej Pilicy i Nadpiliczu, ale jest też miejscem organizacji im-

\footnotetext{
33 Ibidem.

34 www.skansenpilicy.pl.
} 
prez lokalnych, pikników, majówek, ognisk dla zorganizowanych grup czy po prostu miejscem rodzinnych weekendowych wypadów przez cały rok. Ciekawy pomysł, wsparcie dla lokalnego rynku pracy i fakt systematycznego rozwijania obiektu sprawiły, że koncepcja lokalna zyskała szersze uznanie. I tak np. Polska Organizacja Turystyczna w roku 2005 działalność Skansenu Rzeki Pilicy doceniła certyfikatem za Najlepszy Produkt Turystyczny Roku 2005 - „Muzeum bez kapci”, a w plebiscycie na 10 największych atrakcji turystycznych regionu łódzkiego, zorganizowanym przez portal internetowy naszemiasto.pl, Skansen znalazł się w gronie laureatów i otrzymał tytuł „Perła w Koronie Ziemi Łódzkiej 2008”35.

Wydaje się jednak, że formuła samodzielnych działań poszczególnych podmiotów powoli zaczyna się wyczerpywać. Pojawia się za to pewien nowy trend, nawiązujący do zasady „w grupie tkwi siła”, polegający na łączeniu jednostkowych wysiłków na rzecz promowania danego regionu. W działaniach wspólnych, grupowych zawsze łatwiej o nowe pomysły, łatwiej pozyskuje się źródła finansowania dla ich realizacji, choćby z uwagi na skalę działania, ale i nieco inny charakter ma też sama wewnętrzna motywacja realizatorów, kierują się oni nieco odmiennymi pobudkami i aspiracjami. Cel nadrzędny jest jednak zawsze ten sam - promocja obszaru, skutkująca wymiernymi korzyściami gospodarczymi.

Interesującym przykładem kolektywnych działań na rzecz tworzenia koncepcji zintegrowanego produktu turystycznego terenów reprezentowanych przez partnerów współpracy i jego promocji na rynku jest projekt „Moc Atrakcji Turystycznych Regionu Inspirowanych Krainą Świętokrzyską" Lokalnej Grupy Działania „Białe Ługi”36, realizowany we współpracy z pięcioma innymi lokalnymi grupami działania z województwa świętokrzyskiego, a mianowicie Lokalną Grupą Działania „Dorzecze Bobrzy”, Lokalną Grupą Działania „Krzemienny Krąg”, Lokalną Grupą Działania „Nad Czarną i Pilicą”, Stowarzyszeniem LGD „Wokół Łysej Góry” i Stowarzyszeniem Rozwoju Wsi Świętokrzyskiej. W ramach projektu opracowano koncepcję „Szlak przygody”, wykorzystującą lokalne zasoby obszarów wszystkich uczestników projektu dla stworzenia wspólnej sieciowej oferty turystycznej. Terytorium działania podmiotów zaangażowanych podzielono w ramach „Szlaku przygody” na sześć krain tematycznych, proponując korzystanie z charakterystycznych miejscowych atrakcji. I tak w Krainie Talentów można np. zwiedzić dworek Henryka Sienkiewicza w Oblęgorku, w Krainie Kultur odwiedzić synagogi w Chmielniku i Szydłowie czy zespół pałacowo-parkowy w Kurozwękach, w Krainie Natury podziwiać pojezierze świętokrzyskie, modrzewiowy dwór z połowy XVIII wieku w Lutyni czy muzeum etnograficzno-historyczne

\footnotetext{
35 Ibidem.

${ }^{36}$ www.bialelugi.pl, https://www.facebook.com/LGD.Biale.Lugi.
} 
w Fałkowie, w Krainie Sacrum i Profanum dotrzeć do sanktuariów „Relikwi Drzewa Krzyża Świętego" na Świętym Krzyżu czy Matki Boskiej Bolesnej w Kałkowie-Godowie. Kraina 4 Żywiołów to JuraPark w Bałtowie, unikatowe neolityczne kopalnie krzemienia pasiastego w Krzemionkach (gmina Borzechów), starożytne dymarki czy „Żywe Muzeum Porcelany” w Ćmielowie, Kraina Legend proponuje zaś poznanie z bliska opactwa cystersów w Wąchocku, osady średniowiecznej w Hucie Szklanej oraz Babyjagowa czy Parku Rozrywki i Miniatur Sabat Kraj$\mathrm{no}^{37}$. Nowatorskim pomysłem grup zaangażowanych w projekt jest także stworzenie programu lojalnościowego dla turystów, umożliwiającego im zbieranie punktów w czasie zwiedzania miejsc i obiektów na obszarach działania partnerów projektu, na podstawie wydawanej turystom karty, dzięki której zebrane punkty będą mogli wymieniać na nagrody. Dla realizacji tego zamierzenia wspomniane wcześniej sześć LGD powołało do życia fundację „Szlak Przygody”. Fundacja próbuje również zaktywizować inne podmioty z terenów działania LGD oferując możliwość przystąpienia do programu lojalnościowego w charakterze partnera właścicielom gospodarstw agroturystycznych, punktów gastronomicznych czy oferentom innych atrakcji na zasadach indywidualnych umów partnerskich.

\section{Zakończenie}

Po bliższym przyjrzeniu się aktywności lokalnych grup działania można powiedzieć, że dobrze radzą sobie one z wykorzystywaniem dziedzictwa historyczno-kulturowego swoich regionów do tworzenia pozytywnego wizerunku miejsc i skutecznej oferty turystycznej, a pasji i zaangażowania w działania oraz pomysłowości uczyć by się od nich mogli chyba wszyscy polscy samorządowcy.

Badania dotyczące współdziałania samorządów lokalnych z mieszkańcami dla rozwoju turystyki na danym terenie ${ }^{38}$ pokazują, że „mieszkańcy badanych gmin nie są zadowoleni z realizacji zadań samorządu w zakresie zaspokajania potrzeb obywateli”39. Okazuje się bowiem, że ,pomimo zadeklarowanej przez przedstawicieli władz lokalnych współpracy samorządu z mieszkańcami, społeczność lokalna takiej współpracy nie zauważa” ${ }^{40}$. Autorka badań A. Niezgoda uważa, że „taka

37 Ibidem.

${ }_{38}$ Badania empiryczne dotyczyły 3 gmin turystycznych - Ustka/Kartuzy/Bystrzyca Kłodzka - źródło: A. Niezgoda, Wspótpraca i komunikacja władz lokalnych z mieszkańcami - przypadek 3 gmin turystycznych, [w:] Marketing terytorialny..., s. 93-101.

39 A. Niezgoda, op. cit., s. 101.

40 Ibidem, s. 101. 
sytuacja nie jest jedynie wynikiem błędów władz lokalnych, ale wielu czynników, do których należeć mogą czynniki o charakterze ogólnym, dotyczące społeczeństwa polskiego" ${ }^{41}$ i trudno się tu z nią nie zgodzić. Przyczyn takiego stanu rzeczy jest z pewnością wiele. Wśród kluczowych, wyliczanych przez autorkę badań, znalazły się: „,krótkie doświadczenia w procesie rozwoju społeczeństwa demokratycznego; niska świadomość obywatelska; pewien marazm społeczny wynikający z problemów materialnych i niedostosowania do relatywnie krótkiego okresu kapitalizmu, w którym korzyści przynoszą postawy aktywne i przedsiębiorcze"42.

Panaceum na problemy związane z rozwojem turystyki poszczególnych obszarów czy regionów, kreowaniem ich turystycznego wizerunku opartego na lokalnym dziedzictwie historyczno-kulturowym, atmosferze miejsc i unikatowej, również częściowo zaplanowanej tożsamości i systemie samoprezentacji, stać się mogą lokalne grupy działania. Pokazują to choćby opisane wcześniej przykłady. Oczywiście nie ujmując zalet lokalnym grupom działania, takich jak duch przedsiębiorczości, pomysłowość czy działania pełne pasji, pamiętać warto również o przeszkodach, jakie napotykać mogą one na swej drodze. Część z tych przeszkód nawiązuje do wymienianych przez A. Niezgodę czynników hamujących rozwój turystyczny gmin. Do grona najważniejszych w Polsce zaliczyć należałoby po pierwsze niską świadomość obywatelską czy też brak postaw charakterystycznych dla rozwiniętych społeczeństw obywatelskich. Po drugie wynikające ze wspomnianej niskiej świadomości obywatelskiej bardzo wąskie grono osób zainteresowanych tworzeniem LGD czy też aktywnym w nich uczestnictwem. Po trzecie przeszkodę w tworzeniu LGD stanowić może sama dostępność środków unijnych, dziś płynących dość szerokim strumieniem, która z czasem może zostać mocno ograniczona. Po czwarte trudności w tworzeniu i funkcjonowaniu LGD upatrywać należy po stronie know-how pozyskiwania, rozliczania i wykorzystywania pozyskanych środków czy to unijnych, czy od sponsorów i donatorów. Nie można wreszcie zapominać o kwestii stabilności przepisów, których gwałtowne zmiany mogą znacząco wpływać na funkcjonowanie całych sektorów gospodarki, o samych LGD nie wspominając.

Niezależnie jednak od przeszkód i ich liczby to właśnie w inicjatywach lokalnych, takich jak podejmowane przez lokalne grupy działania, i w wizjach pasjonatów, kryje się nieugięta siła kreowania zmian otaczającej nas rzeczywistości na lepsze.

\footnotetext{
41 Ibidem.

42 Ibidem.
} 


\section{Bibliografia}

Czynnik ludzki a marketing terytorialny, red. T.M. Łaguna, Wyd. Wszechnica Warmińska, Lidzbark Warmiński 2009

Florek M., Podstawy marketingu terytorialnego, Wyd. Akademii Ekonomicznej w Poznaniu, Poznań 2006

Florek M., Janiszewska K., Marketing terytorialny. Studia przypadków, Wyd. Akademii Ekonomicznej w Poznaniu, Poznań 2008

Florek M., Janiszewska K., Marketing terytorialny w aglomeracji poznańskiej, Bogucki Wydawnictwo Naukowe, Poznań 2010

Makarski S., Kuźniar W., Marketing $w$ zarządzaniu jednostka terytorialna na przykładzie województwa podkarpackiego, Wyd. Uniwersytetu Rzeszowskiego, Rzeszów 2009

Marketing terytorialny $w$ budowaniu konkurencyjności podmiotów publicznych, red. A. Siedlecka, A. Smarzewska, M. Zwolińska-Ligaj, Wyd. Państwowej Wyższej Szkoły im. Jana Pawła II w Białej Podlaskiej, Biała Podlaska 2012 Szromnik A., Marketing terytorialny. Miasto i region na rynku, Oficyna Wolters Kluwer Business, Kraków 2007

Transfer wiedzy i działan innowacyjnych $w$ obszarze agrobiznesu: uwarunkowania, mechanizmy, efekty, red. S. Makarski, Wyd. Uniwersytetu Rzeszowskiego, Rzeszów 2007

Wizerunek regionu o orientacji rynkowej, red. A. Siedlecka, A. Smarzewska, M. Zwolińska-Ligaj, J. Kamiński, Wyd. Państwowej Szkoły Wyższej im. Papieża Jana Pawła II w Białej Podlaskiej, Biała Podlaska 2012

https://www.arimr.gov.pl https://www.bialelugi.pl https://www.bieliny.pl https://www.juraparkbaltow.pl https://www.parkmania.pl https://www.pot.gov.pl https://www.skansenpilicy.pl https://www.traveltime.info.pl https://www.zambrow.org https://www.zielonypierscien.pl 